\title{
Application of Agricultural Wastes Activated Carbon for Dye Removal - An Overview
}

\author{
Amirza, M. A. R. ${ }^{1}$, Adib, M. M. R. ${ }^{1,}{ }^{*}$, and Hamdan, ${ }^{2}{ }^{2}$ \\ ${ }^{1}$ Department of Water and Environmental Engineering, Faculty of Civil and Environmental \\ Engineering, Universiti Tun Hussein Onn Malaysia, 86400 Batu Pahat, Johor, Malaysia. \\ ${ }^{2}$ Department of Chemistry Engineering Technology, Faculty of Chemistry Engineering Technology, \\ Universiti Tun Hussein Onn Malaysia, 86400 Batu Pahat, Johor, Malaysia.
}

\begin{abstract}
Dyes are an important class of pollutants and can even be identified by the human eyes. Disposal of dyes in precious water resources must be avoided especially those that are not easily biodegradable, however, and for that various treatment technologies are in use. Among various methods adsorption occupies a prominent place in dye removal. The growing demand for efficient and low-cost treatment methods and the importance of adsorption has given rise to agricultural waste. This review highlights and provides an overview of these activated carbons prepared by non-woody and woody materials and their application for dyes removal. From a comprehensive literature review, it was found that many researchers used non-woody material as activated carbons to removal dye contaminants.
\end{abstract}

\section{Introduction}

Saving water to rescue the planet from water polluted situation and to make the future of mankind being safe is what we need now. With the growth of mankind, society, science and technology our world is reaching to new high horizons but the cost which we are paying or will pay in near future is surely going to be too high. Among the consequences of this rapid growth is environmental disorder with a big pollution problem. Besides other needs the demand for water consumption ("Water for People Water for Life" United Nations World Water Development Report UNESCO) has increased tremendously with agricultural, industrial and domestic sectors consuming 70, 22 and $8 \%$ of the available fresh water, respectively and this has resulted in the generation of large amounts of wastewater [1] containing a number of 'pollutants'.

In recent years, properties of dyes solution as their visibility and recalcitrance generate problem for various industries such as manufacturing of fabrics, paper, silk, cotton, cosmetics and textile [2-16] in order to color their products [4, 6, 10, 17-28]. Wastewater contaminated by synthetic azo-dyes have complex aromatic molecular structure which make them inert and biodegradable [12, 14-15, 29-31] difficult when discharged into the environment $[3,5,8,10-11,16,26]$ if not being removed properly [13, 27, 32-34]. The

\footnotetext{
Corresponding author: adib@uthm.edu.my
} 
worldwide production of synthetic dyes is estimated at $7 \times 10^{5}$ to $1 \times 10^{6}$ tons dyestuff [28] produced annually with $10 \%-60 \%$ of dye-containing effluents are emitted into the environment without proper treatment $[5,9,12,22,28,30,35]$. Dyes contaminants from industrial disposal cause severe problems associated, as dyes given toxicity $[12,14-15,27$, $30-31]$ to the aquatic flora and fauna life that are present in the ecosystem [2-4, 8-11, 20-23, $25,36]$. The effluent of dyes may damaging the aesthetic nature of the environment $[2,4$, $18,23,25,27,32,35,37-38]$ includes visible pollution, reduce photosynthetic activities and not readily biodegradable by the indigenous [2, 4-6, 8, 22, 25, 28, 31, 36, 38], even at low concentrations $[15,17,19,35]$. As well as the potential mutagenic and carcinogenic effects of cancer $[2,3,5,9,11,15,19-23,28,31,36]$ after transformations or degradation yield compounds such as benzidine, toluidine and other aromatic amines $[8,25,32,35,39$ $40]$ are indiscriminately. Where certain dyes were determined to have a direct effect on the newly formed micronuclei, chromosomal breakage and aneuploidy in human cells [19]. The dyes also can cause severe damage to human beings such as allergy dermatitis $[3,9,36]$, skin irritation [3, 9, 26, 36], dysfunction of kidney [25], reproductive system, liver, brain and central nervous system [2, 20, 25].

Conventional techniques available for dye removal such as photo-catalytic degradation $[3,7-8,15,21,25,36]$, Fenton degradation, electrochemical degradation [3-4, 8, 14, 21-22, $26,33,36,41]$, electrocoagulation [8, 11, 15, 26], liquid-liquid extraction [21], irradiation, biodegradation [6], photochemical [11], coagulation-flocculation [12, 16, 20, 27, 37], membrane filtration $[6,16,21,27,29]$, ultrafiltration membrane $[3,15]$, ion exchange [29, $32]$ and persulfate oxidation $[2,16-18,27,40]$ is efficient and economically feasible but it also create secondary pollution notably spent catalyst and fouled membrane that requires further disposal [19]. However, these conventional methods have proven to display low effectiveness of dye removal inherent constraints due to their high cost [13, 29], high energy requirements and generation of hazardous by-products $[2,6,32,33,37,38]$ caused by their complex aromatic compounds [25].

In additional to already mentioned methods, the adsorption process has been widely being used for dyes removal. Adsorption techniques particularly by carbon adsorbents has emerged to be the best one of the most promising alternatives [3, 5-6, 9-12, 22-23, 27, 30] efficient technology, which finds diverse applications in several disciplines of purification and decontamination processes [34] for the removal of organic pollutants from wastewaters. Factors that affect the adsorption technique in terms of initial cost, simplicity of design, ease of operation, high removal efficiently, regeneration capacity and insensitivity to toxic substances $[5,18-19,21-22,25-26,29-30,40]$ have been found to be among the most effective and proven treatments of dye-loaded wastewater. The adsorptive properties of activated carbon depends on the surface area, good internal porous structure, high thermal stability, low acid/base reactivity and chemical structure of the surface [35, $38,43]$.

The most important characteristics of an adsorbent are the quantity of adsorbate it can accumulate which is usually calculated from the adsorption isotherms. Dyes that are difficult to biological breakdown can often be removed by using the adsorbents. A good adsorbent should generally possess a porous structure (resulting in high surface area) and the time taken for adsorption equilibrium to be established should be as small as possible so that it can be used to remove dye wastes in lesser time.

\section{Production of Activated Carbon from Agricultural Waste}

Generally, activated carbons (ACs) is considered as the most commonly used adsorbent in water and wastewater treatment worldwide $[16,42]$. The properties of ACs are a tasteless, solid, microcrystalline, non-graphitic form of black carbonaceous material with a porous 
structure [16]. ACs has been regarded as a unique and versatile adsorbent due to its extended surface area [26, 28-29, 31], micro porous structure [26], good chemical and mechanical stability, high adsorption capacity $[26,29]$. The high degree of activated carbon surface reactivity are caused by heterogeneous porous structures [28-29] which make them perfect adsorbents $[11,15,17-19,21,27,32-33,36,43-46]$. The ACs can be produced from a variety of natural and synthetic substances, where lignocelluloses materials being one of the most used precursors [42]. The composition of the lignocelluloses material regarding the cellulose, hemicellulose and lignin content determines, to some extent, the porosity development of the produced ACs [24, 28]. However, a major challenge of commercial available activated carbon (CAC) are still considered expensive materials for many countries due to the use of non-renewable and relatively expensive starting materials such as coal $[2-7,9,12-13,19,22,26-28,30,35-36,38,46]$ but poor regeneration limit its potential usage in the treatment system $[2,7,11,13,27-28,32,37]$. Commonly in market, commercial activated carbon (CAC) was sales in range of $\mathrm{RM} 90.00 / \mathrm{Kg}$, however for production of sugarcane bagasse activated carbon (SBAC) was in range of RM12.00/Kg. For that reason, production of SBAC using lower heating temperature $\left(500^{\circ} \mathrm{C}\right)$ and using raw material from agricultural waste compared with $\mathrm{CAC}$ being used higher heating temperature $\left(\geq 1000^{\circ} \mathrm{C}\right)$.

Therefore, ACs obtained from agricultural byproducts has the advantage of offering an effective [4, 27, 47,], low cost replacement for non-renewable coal-based granular activated carbon (GAC) [3, 8-11, 24, 27-29, 36] may provide that they have similar of better adsorption efficiency [25,43] such as solid pineapple waste [17], oil palm empty fruit bunches [44], Thevetia peruviana [18], cattail [46], peanut shell [40], rambutan (Nephelium lappaceum) [35], banana empty fruit bunch (BEFB) and delonix regia fruit pod (DRFP) [43], palm shell waste-based [37], coir pith [32], orange peel [38], sawdust and rice-husk [19]. The production of activated carbon prepared from agricultural waste can be revised based on non-woody materials (Table 1) and woody materials (Table 2).

Apparently, activated carbons are prepared by physical and chemical activation processes [15]. In physical activation also known as pyrolysis process, the precursor is being carbonized at high temperature and activated by passing $\mathrm{CO}_{2}$ of steam under pressure to increase the porosity and surface area $[8,28]$. Meanwhile, in chemical activation, both activation and carbonization process take place simultaneously in which the raw precursor is impregnated with activating agents and heated at desired temperature $[5,8,25,28,48]$. Chemical activation leads to both physical and chemical modifications on produce activated carbon. The agricultural wastes provide both woody and non-woody materials for adsorption methods replaced with commercial activated carbon. For woody materials composed lignocellulose only compared with non-woody materials composed sugar, starch, lignocellulose and oils [49]. Many authors used non-woody materials due to the composition of materials such as starch and lignocellulose which have high pore structure compared with woody materials.

Based on the review of Table 1 and Table 2 for materials woody and non-woody, it can be concluded that specific surface area of activated carbon produced depends significantly on the type of materials and activating agents used in the adsorption processes. Specific surface area was important parameters used in evaluating many capabilities of powders and porous materials such as activity, adsorptive performance and catalytic performance [50]. The factors affecting on the measured value of specific surface area of activated carbon such as degassing temperature, degassing time and adsorption point number.

Certain agricultural waste products have been tested and proposed for dye removal. Which agricultural waste adsorbent is better to being used? There is no direct answer to this question due to their each agricultural waste has its specific physical and chemical characteristics such as porosity, surface area and physical strength, as well as inherent 
advantages and disadvantages in wastewater treatment. However, it is clear from the present literature survey that agricultural waste adsorbents may have potential as readily available, inexpensive and effective sorbents. They also possess several other advantages that make them excellent materials for environmental purposes such as high surface area (Table 1 and 2).

Table 1. Non-woody materials of agricultural waste activated carbon.

\begin{tabular}{|c|c|c|c|c|}
\hline Raw precursor & $\begin{array}{c}\text { Chemical used in } \\
\text { impregnation } \\
\text { method }\end{array}$ & $\begin{array}{l}\text { Pollutants in dye } \\
\text { removal }\end{array}$ & $\begin{array}{l}\text { Specific surface } \\
\text { area analysis } \\
(\text { BET })\left(\mathrm{m}^{2} / \mathrm{g}\right) \\
\end{array}$ & Ref. \\
\hline Pomegranate peel & $\begin{array}{c}\mathrm{ZnCl}_{2}, \text { nitric acid } \\
\text { solution }\end{array}$ & Dye direct blue 106 & - & [2] \\
\hline Orange peel & $\mathrm{H}_{2} \mathrm{SO}_{4}$ & $\begin{array}{l}\text { Dye direct navy blue } \\
106\end{array}$ & - & [3] \\
\hline Coir pith & $\mathrm{H}_{2} \mathrm{SO}_{4}$ & $\begin{array}{c}\text { Dyes reactive orange } \\
12 \text {, reactive red } 2 \\
\text { and reactive blue } 4\end{array}$ & $\begin{array}{c}\text { Coir pith carbon } \\
\text { (598) and Granular } \\
\text { coir pith carbon } \\
(557)\end{array}$ & [12] \\
\hline Rice husk & $\mathrm{H}_{2} \mathrm{SO}_{4}$ & $\begin{array}{c}\text { Dyes crystal violet, } \\
\text { direct orange and } \\
\text { magenta }\end{array}$ & 98.27 & [13] \\
\hline Rice husk & - & $\begin{array}{c}\text { Dyes congo red and } \\
\text { magenta }\end{array}$ & - & [14] \\
\hline Sugarcane bagasse & $\mathrm{ZnCl}_{2}$ & Basic dye & - & {$[15]$} \\
\hline Hazelnut bagasse & $\mathrm{ZnCl}_{2}$ & Dye acid blue 350 & 1489 & [16] \\
\hline $\begin{array}{c}\text { Solid pineapple } \\
\text { waste biomass, } \\
\text { SPWB (crown, } \\
\text { leaves, stem) }\end{array}$ & $\mathrm{ZnCl}_{2}$ & $\begin{array}{l}\text { Dye methylene blue } \\
\text { (MB) }\end{array}$ & $\begin{array}{c}1002 \text { (leaf), } 955 \\
\text { (stem), } 794 \text { (crown) }\end{array}$ & [17] \\
\hline Thevetia peruviana & $\begin{array}{c}\mathrm{Na}_{2} \mathrm{SO}_{4}, \mathrm{H}_{3} \mathrm{PO}_{4}, \\
\mathrm{ZnCl}_{2}, \mathrm{KOH}, \mathrm{HCl} \text {, } \\
\mathrm{H}_{2} \mathrm{SO}_{4} \text {, direct } \\
\text { pyrolysis, } \\
\text { dolomite, } \mathrm{H}_{2} \mathrm{SO}_{4}+ \\
\mathrm{H}_{2} \mathrm{O}_{2}\end{array}$ & $\begin{array}{l}\text { Dyes methylene blue } \\
\text { (MB), Basic green } 4, \\
\text { Acid violet } 49, \\
\text { Reactive orange } 4 \\
\text { and Direct blue } 71\end{array}$ & $\begin{array}{c}329.27(\text { pyrolysis }), \\
205.63\left(\mathrm{Na}_{2} \mathrm{SO}_{4}\right), \\
862.39\left(\mathrm{H}_{3} \mathrm{PO}_{4}\right), \\
503.77\left(\mathrm{ZnCl}_{2}\right), \\
561.1(\mathrm{KOH}), \\
156.24(\mathrm{HCl}), \\
390.69\left(\mathrm{H}_{2} \mathrm{SO}_{4}\right), \\
\text { 85.93( }\left(\mathrm{Dolomite}^{2}\right) \\
299.85\left(\mathrm{H}_{2} \mathrm{SO}_{4}+\right. \\
\left.\mathrm{H}_{2} \mathrm{O}_{2}\right)\end{array}$ & {$[18]$} \\
\hline $\begin{array}{c}\text { Sawdust and rice- } \\
\text { husk }\end{array}$ & - & Dye acid yellow 36 & $\begin{array}{c}\text { Sawdust carbon was } \\
516.3 \text { while rice- } \\
\text { husk was } 272.5\end{array}$ & {$[19]$} \\
\hline $\begin{array}{c}\text { Silk cotton hull, } \\
\text { coconut tree } \\
\text { sawdust, sago waste, } \\
\text { maize cob, banana } \\
\text { pith }\end{array}$ & $\mathrm{H}_{2} \mathrm{SO}_{4}$ & $\begin{array}{c}\text { Dyes were } \\
\text { rhodamine-B, congo } \\
\text { red, methylene blue, } \\
\text { methyl violet, } \\
\text { malachite green }\end{array}$ & - & {$[20]$} \\
\hline Flamboyant pods & $\mathrm{NaOH}$ & $\begin{array}{l}\text { Dyes acid yellow 6, } \\
\text { acid yellow } 23 \text { and } \\
\text { acid red } 18\end{array}$ & 2854 & [23] \\
\hline Esparto grass & - & - & 1122 & {$[24]$} \\
\hline Avocado peel & - & $\begin{array}{c}\text { Dyes naphthol blue } \\
\text { black and reactive } \\
\text { black } 5 \text { and basic } \\
\text { blue } 41\end{array}$ & $\begin{array}{l}53 \text { (raw material) } \\
\text { and } 452 \text { (after } \\
\text { carbonization) }\end{array}$ & {$[25]$} \\
\hline
\end{tabular}


Table 1. Non-woody materials of agricultural waste activated carbon (Cont...)

\begin{tabular}{|c|c|c|c|c|}
\hline Raw precursor & $\begin{array}{c}\text { Chemical used in } \\
\text { impregnation } \\
\text { method }\end{array}$ & $\begin{array}{l}\text { Pollutants in dye } \\
\text { removal }\end{array}$ & $\begin{array}{l}\text { Specific surface } \\
\text { area analysis } \\
\text { (BET) }\left(\mathrm{m}^{2} / \mathrm{g}\right)\end{array}$ & Ref \\
\hline $\begin{array}{c}\text { Sugarcane bagasse } \\
\text { pith }\end{array}$ & $\mathrm{H}_{3} \mathrm{PO}_{4}$ and $\mathrm{ZnCl}_{2}$ & Dye reactive orange & - & {$[27]$} \\
\hline $\begin{array}{c}\text { Grape processing } \\
\text { waste }\end{array}$ & $\mathrm{ZnCl}_{2}$ & $\begin{array}{l}\text { Dyes methylene blue } \\
\text { and metanil yellow }\end{array}$ & 1455 & {$[28]$} \\
\hline Apple pulp and peel & $\mathrm{H}_{3} \mathrm{PO}_{4}$ & Dye methylene blue & $\begin{array}{c}1552 \text { (apple peel) } \\
\text { and } 1103 \text { (apple } \\
\text { pulp) }\end{array}$ & {$[29]$} \\
\hline Orange peel & $\mathrm{H}_{3} \mathrm{PO}_{4}$ & $\begin{array}{l}\text { Dyes methylene blue } \\
\text { and rhodamine B }\end{array}$ & 1090 & {$[30]$} \\
\hline $\begin{array}{l}\text { Prickly pear peels, } \\
\text { broccoli stems and } \\
\text { white sapote seeds }\end{array}$ & $\mathrm{H}_{3} \mathrm{PO}_{4}$ & $\begin{array}{l}\text { Dyes acid blue } 74, \\
\text { direct blue } 80 \text {, basic } \\
\text { blue } 9 \text { and basic } \\
\text { violet } 3\end{array}$ & $\begin{array}{c}1025 \text { (prickly pear } \\
\text { peels), } 1177 \\
\text { (broccoli stems) and } \\
1043 \text { (white sapote } \\
\text { seeds) }\end{array}$ & {$[31]$} \\
\hline Coir pith & $\mathrm{ZnCl}_{2}$ & $\begin{array}{l}\text { Dyes acid brilliant } \\
\text { blue, acid violet, } \\
\text { methylene blue, } \\
\text { rhodamine } \mathrm{B}, \text { direct } \\
\text { red } 12 \mathrm{~B} \text {, congo red, } \\
\text { procion red, procion } \\
\text { orange }\end{array}$ & $\begin{array}{c}\text { Precursor presence } \\
\text { of } \mathrm{ZnCl}_{2} \text { was } 910 \\
\text { and } 167 \text { for absence } \\
\text { of } \mathrm{ZnCl}_{2}\end{array}$ & {$[32]$} \\
\hline $\begin{array}{l}\text { Jerusalem artichoke } \\
\text { stalk-based }\end{array}$ & $\mathrm{ZnCl}_{2}$ & $\begin{array}{l}\text { Dyes methy orange } \\
\text { and methylene blue }\end{array}$ & $\begin{array}{c}\text { Jerusalem artichoke } \\
\text { AC was } 1632 \\
\text { compared to PAC } \\
\text { was } 1410 \text { and } 582 \\
\text { for GAC }\end{array}$ & {$[33]$} \\
\hline Pomela skin & $\mathrm{NaOH}$ & $\begin{array}{l}\text { Dyes methylene blue } \\
\text { and acid blue } 15\end{array}$ & $\begin{array}{c}52 \text { (Char) and } 1335 \\
\text { (PSAC) }\end{array}$ & {$[34]$} \\
\hline $\begin{array}{l}\text { Rambutan } \\
\text { (Nephelium } \\
\text { lappaceum) }\end{array}$ & $\mathrm{KOH}$ & Dye acid yellow 17 & 971.54 & {$[35]$} \\
\hline Orange peel & $\mathrm{H}_{2} \mathrm{SO}_{4}+\mathrm{NaHCO}_{3}$ & Dye methylene blue & - & {$[38]$} \\
\hline $\begin{array}{c}\text { Tomato processing } \\
\text { solid waste }\end{array}$ & $\mathrm{ZnCl}_{2}$ & $\begin{array}{l}\text { Dyes methylene blue } \\
\text { and metanil yellow }\end{array}$ & 1093 & {$[41]$} \\
\hline Date palm leaflets & $\mathrm{KOH}$ & Dye methylene blue & 823 & {$[42]$} \\
\hline $\begin{array}{l}\text { Banana empty fruit } \\
\text { bunch (BEFB) and } \\
\text { Deloxia regia fruit } \\
\text { pod (DRFP) }\end{array}$ & $\mathrm{H}_{3} \mathrm{PO}_{4}, \mathrm{KOH}$ & $\begin{array}{l}\text { Dye methylene blue } \\
\text { (MB) }\end{array}$ & $\begin{array}{c}\text { BEFB for } 0.32 \\
\text { (untreated), } 15.38 \\
\left(\mathrm{H}_{3} \mathrm{PO}_{4}\right) \text { and } 1.04 \\
(\mathrm{KOH}) \\
\text { DRFP for } 17.55 \\
\text { (untreated), } 22.29 \\
\left(\mathrm{H}_{3} \mathrm{PO}_{4}\right) \text { and } 0.01 \\
(\mathrm{KOH}) \\
\end{array}$ & {$[43]$} \\
\hline Cattail & $\mathrm{H}_{3} \mathrm{PO}_{4}$ & $\begin{array}{c}\text { Dyes Neutral red } \\
\text { and Malachite green }\end{array}$ & 1279 & {$[46]$} \\
\hline Corncob & $\mathrm{H}_{3} \mathrm{PO}_{4}$ & Dye methylene blue & 1809 & {$[47]$} \\
\hline
\end{tabular}

Table 1 represents some of the non-woody materials of agricultural waste of activated carbon reported. From the recent literature reviewed, adsorbents that stand out for high surface area are flamboyant pods $\left(2854 \mathrm{~m}^{2} / \mathrm{g}\right)$, corncob $\left(1809 \mathrm{~m}^{2} / \mathrm{g}\right)$, Jerusalem artichoke 
$\left(1632 \mathrm{~m}^{2} / \mathrm{g}\right)$, apple peel $\left(1552 \mathrm{~m}^{2} / \mathrm{g}\right)$, hazelnut bagasse and grape waste with the surface area of $\left(1489 \mathrm{~m}^{2} / \mathrm{g}\right)$ and $\left(1455 \mathrm{~m}^{2} / \mathrm{g}\right)$. As usual, the solution $\mathrm{pH}$ is an important parameter in the adsorption process due to the interaction effect of the surface functional groups of the adsorbate and the adsorbent. Besides that, the properties of the activated carbon and of the dyes may indicate whether adsorption process is favorable in acid or base solutions.

[23] stated that at initial concentration of $500 \mathrm{mg} / \mathrm{L}$, the maximum removal percentages of activated carbon from flamboyant pods were $99.88 \%, 99.87 \%$ and $98.97 \%$ for acid yellow 6, acid yellow 13 and acid red 18 dyes, respectively. Activated carbons prepared by Jerusalem artichoke stalk based mesoporous (MAC) were studied as adsorbents [33] for adsorption removal of anionic (methyl orange, MO) and cationic dyes (methylene blue, $\mathrm{MB})$. It was observed that the amount of dyes adsorbed, $\mathrm{q}_{\mathrm{t}}(\mathrm{mg} / \mathrm{g})$ values increased from $170.2 \mathrm{mg} / \mathrm{g}$ to $223.7 \mathrm{mg} / \mathrm{g}$ with the $\mathrm{pH}$ value increased from 3.44 to 10.6 at initial $60 \mathrm{~min}$ for $\mathrm{MO}$ dye, but different condition for anionic dye (MO) stated that the $\mathrm{q}_{\mathrm{t}}$ value decreased from $238.1 \mathrm{mg} / \mathrm{g}$ to $179.3 \mathrm{mg} / \mathrm{g}$ when $\mathrm{pH}$ was increased from 3.15 to 10.7 at initial $60 \mathrm{~min}$. For instance, the MAC becomes negatively charged, which may produce a considerable high electrostatic attraction to simulate the MB moving toward the MAC surface, but when $\mathrm{pH}$ value was lower than $\mathrm{pH}_{\mathrm{pzc}}$ (3.70) condition, the surface of MAC is positively charged by adsorbing $\mathrm{H}^{+}$ions which is attractive to the anionic dye due to electrostatic repulsion between MO and negative charges on the MAC surface. Therefore, the authors suggested that the electrostatic interaction attraction may enhance the adsorption rate but is not the primary adsorption mechanism between the cationic dye and the partially negative charge MAC surface.

Grape processing waste (GW) was studied by Saygili et al., (2015) for the adsorption of methylene blue (MB) and metanil yellow (MY) dyes. The authors investigated the impregnation ratio of $\mathrm{ZnCl}_{2}$ increased from 1:1 to $1: 6\left(\mathrm{GW} / \mathrm{ZnCl}_{2}\right)$, the surface area values also increased from $911 \mathrm{~m}^{2} / \mathrm{g}$ to $1361 \mathrm{~m}^{2} / \mathrm{g}$, respectively. It is obvious that impregnated with chemical as an activating agent is very efficient in order to produced ACs with high surface area and porosity. Due to the chemical activation, the equilibrium data for both dye adsorptions onto grape processing waste activated carbon (GWAC), showing the maximum monolayer adsorption capacity of $417 \mathrm{mg} / \mathrm{g}$ for $\mathrm{MB}$ and $386 \mathrm{mg} / \mathrm{g}$ for MY. This may attributed to the fact that $\mathrm{ZnCl}_{2}$ selectively extracted $\mathrm{H}$ and $\mathrm{O}$ away from the $\mathrm{GW}$ rather than ACs. Hence, this causes eventually to an increase in the surface area and porosity [51].

Due to their low cost and local availability, agricultural wastes such as Fox nutshell and Holm oak acorn are classified as woody materials (Table 2) and can produced activated carbon used as adsorbents for dye removal [10, 21]. Recently, [21] studied the removal of methylene blue and phenol onto activated carbon from Fox nutshell (FNAC) by chemical activation $\left(\mathrm{ZnCl}_{2}\right)$. The maximum \% removal of $\mathrm{MB}$ was observed at $\mathrm{pH} 11$. Similar results are reported for the adsorption of methylene blue on Jute fiber and wheat shells [52-53]. When the $\mathrm{pH}$ value decreased at $\mathrm{pH} 3$, the authors found that the low adsorption rate of $\mathrm{MB}$ occurred on FNAC due to the positive charged on the surface, causing $\mathrm{H}^{+}$ions to compete effectively with MB cations. The equilibrium adsorption of MB was increased from 249.88 tom $968.74 \mathrm{mg} / \mathrm{g}$ which indicates that the MB adsorption process onto FNAC was exothermic in nature.

[10] studied that the highest micropore percentages was obtained using $\mathrm{KOH}$ as an activating agent for activated carbon from Holk oak acorn. Further, in order to know the effect of chemical treatment and to improve its efficiency the authors also tested the potential of the adsorbent by treating it with $\mathrm{H}_{3} \mathrm{PO}_{4}$ and using $\mathrm{ZnCl}_{2}$, found that activated carbons obtained by $\mathrm{H}_{3} \mathrm{PO}_{4}$ had a mesopore structure while those obtained from $\mathrm{ZnCl}_{2}$ had a heterogeneous pore distribution consisting of micropores and mesopores. Similar to the findings of [54] preparation of activated carbons from sewage sludge via chemical activation using $\mathrm{H}_{3} \mathrm{PO}_{4}$ may contribute large mesoporous and some microporous being 
observed for all activated carbons. The increase in surface area of ACs due to a phosphoric acid reagent has been explained in the reviews as $\mathrm{H}_{3} \mathrm{PO}_{4}$ aiding the thermal decomposition of the lignocelluloses material.

Table 2. Woody materials of agricultural waste activated carbon.

\begin{tabular}{|c|c|c|c|c|}
\hline Raw precursor & $\begin{array}{c}\text { Chemical used in } \\
\text { impregnation } \\
\text { method }\end{array}$ & $\begin{array}{l}\text { Pollutants in dye } \\
\text { removal }\end{array}$ & $\begin{array}{l}\text { Specific surface } \\
\text { area analysis } \\
(\text { BET })\left(\mathrm{m}^{2} / \mathrm{g}\right)\end{array}$ & Ref. \\
\hline Coconut shell & $\mathrm{H}_{3} \mathrm{PO}_{4}$ & $\begin{array}{c}\text { Dye yellow } \\
\text { (Tartrazine E102) }\end{array}$ & 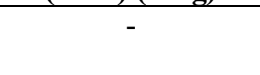 & {$[4]$} \\
\hline Cocoa shell & $\begin{array}{c}\text { Red mud + lime + } \\
\mathrm{KOH}+\mathrm{Al}\left(\mathrm{NO}_{3}\right)_{3}+ \\
\mathrm{Na}_{2} \mathrm{SO}_{4}\end{array}$ & Dye reactive violet 5 & - & [5] \\
\hline Macore fruit & $\mathrm{NaOH}$ & $\begin{array}{l}\text { Dyes methylene blue } \\
\text { and methyl orange }\end{array}$ & 229.51 & [6] \\
\hline Cashew nut shell & $\begin{array}{c}\mathrm{KOH}+\mathrm{TiO}_{2}, \\
\mathrm{KOH}, \mathrm{TiO}_{2}\end{array}$ & $\begin{array}{l}\text { Dyes brilliant green } \\
\text { and methylene blue }\end{array}$ & - & [7] \\
\hline $\begin{array}{c}\text { Walnut and poplar } \\
\text { woods }\end{array}$ & $\mathrm{H}_{3} \mathrm{PO}_{4}$ & Dye acid red 18 & - & [8] \\
\hline Coconut shell & $\mathrm{H}_{3} \mathrm{PO}_{4}$ & Dye reactive blue 19 & - & [9] \\
\hline Holm oak acorn & $\begin{array}{c}\mathrm{KOH}, \mathrm{ZnCl}_{2}, \\
\mathrm{H}_{3} \mathrm{PO}_{4}, \mathrm{H}_{2} \mathrm{SO}_{4}\end{array}$ & $\begin{array}{c}\text { Dye disperse orange } \\
30\end{array}$ & $\begin{array}{c}968\left(\mathrm{H}_{3} \mathrm{PO}_{4},\right. \\
\left.550^{\circ} \mathrm{C}\right), 1305 \\
\left(\mathrm{ZnCl}_{2}, 750^{\circ} \mathrm{C}\right), \\
582\left(\mathrm{KOH}, 750^{\circ} \mathrm{C}\right)\end{array}$ & {$[10]$} \\
\hline Apricot stones & $\mathrm{H}_{3} \mathrm{PO}_{4}+\mathrm{HNO}_{3}$ & $\begin{array}{l}\text { Dyes methyl orange } \\
\text { and methylene blue }\end{array}$ & $\begin{array}{c}359.40\left(\mathrm{H}_{3} \mathrm{PO}_{4}+\right. \\
\left.\mathrm{HNO}_{3}\right) \text { and } \\
\text { commercial } \\
\text { activated carbon } \\
(510.57)\end{array}$ & {$[11]$} \\
\hline Fox nutshell & $\mathrm{ZnCl}_{2}$ & $\begin{array}{l}\text { Dye methylene blue } \\
\text { (MB) }\end{array}$ & 2869 & {$[21]$} \\
\hline $\begin{array}{l}\text { Spent coffee } \\
\text { grounds }\end{array}$ & $\mathrm{KOH}$ & $\begin{array}{l}\text { Acid orange } 7 \text { and } \\
\text { methylene blue }\end{array}$ & 704.23 & {$[22]$} \\
\hline Peanut sticks wood & $\mathrm{HCl}$ and $\mathrm{HNO}_{3}$ & Dye methylene blue & 218.89 & {$[26]$} \\
\hline Olive stone & - & Dye methylene blue & - & {$[36]$} \\
\hline $\begin{array}{c}\text { Palm shell-waste } \\
\text { based }\end{array}$ & $\mathrm{NaOH}$ & $\begin{array}{l}\text { Dye methylene blue } \\
(\mathrm{MB})\end{array}$ & 731.50 & {$[37]$} \\
\hline Peanut shell & $\begin{array}{c}\text { Conventional } \\
\text { pyrolysis (P } \\
\text { sample) and } \\
\text { microwave } \\
\text { irradiation followed } \\
\text { by pyrolysis (MW- } \\
\text { P sample) }\end{array}$ & $\begin{array}{l}\text { Dyes Direct black } 38 \\
\text { and reactive red } 141\end{array}$ & $\begin{array}{c}370.10 \text { (P sample) } \\
\text { and } 395.80 \text { (MW- } \\
\text { P sample) }\end{array}$ & {$[40]$} \\
\hline
\end{tabular}

\section{CONCLUSIONS}

The majority of the reviewed studies concluded that a wide range of activated carbons prepared from agricultural waste as adsorbents of dye removal. It is worthwhile noting that the removal of dyes can be done by various materials such as non-woody and woody waste. However, there exists no such methodology of which activated carbons can successfully remove all types of dyes at low cost adsorbents. The agricultural waste is converted into value-added materials as activated carbons, which are generated in huge amounts annually. The modification of the surface chemistry of carbons is also an important influenced, 
although depending on the raw materials of activated carbon, both increases and decreases in surface area have been reported. It has been generally shown that many researchers using agricultural waste from non-woody materials compared to woody materials in term of removal dyes in water polluted. As a reason, non-woody materials is ease to be conducted and chemical composition of these agricultural waste have high ash content and fiber such as hemicellulose, cellulose and lignin which may reduce the mechanical strength and adsorption capacity of activated carbon.

As environmental regulations become stricter, the effectiveness and cost of treatment processes for dye becomes more significant. Instead, the dye removal data available in literature suggests that removal of dyes is possible by agricultural waste to a certain extent since some promising results are obtained in some of the studies. Therefore, it is understood that impregnation ratio of chemical activating agents significantly affect to porosity. With low impregnation ratio, the formation of tar is inhibited and the release of volatiles is promoted, producing more mesopores. Rather at higher impregnation ratio, the more swelling impregnated precursor materials and stronger release of volatiles in the activation process will be lead to the widening of pores: micropores formed are subsequently converted to mesopores [55]. The application of activated carbon in adsorption process was mainly depends on the surface chemistry and pore structure or porous carbons. If possible, develop modification of surface chemical activation method on activated carbon prepared by non-woody material should be provided. Various methods should be produced such as acidic treatment and alkaline treatment.

This paper was partly sponsored by the Centre for Graduate Studies UTHM. The author also would like to express gratitude to the Ministry of Education Malaysia under Postgraduate Research Grant Scheme (FRGS: Vot 1456), Department of Environment Malaysia (DOE) and Universiti Tun Hussein Onn Malaysia for the support in preparing this paper. Grateful acknowledgement also goes to all that are involved directly or indirectly to completing this paper.

\section{References}

[1] V.K. Gupta and Suhas, Application of low-cost adsorbents for dye removal: a review, J. of Environmental Management, 90, 2313-2342, (2009)

[2] N.K. Amin, Removal of direct blue 106 dye from aqueous solution using new activated carbons developed from pomegranate peel: adsorption equilibrium and kinetics, J. of Hazardous Materials, 165, 52-62, (2009)

[3] A. Khaled, A.E. Nemr, A. El-Sikaily and O. Abdelwahab, Removal of direct N blue 106 from artificial textile dye effluent using activated carbon from orange peel: adsorption isotherm and kinetic studies, J. of Hazardous Materials, 165, 100-110, (2009)

[4] M. Jibril, J. Noraini, L.S. Poh and A.M. Evuti, Removal of color from waste water using Coconut Shell Activated Carbon (CSAC) and commercial Activated Carbon (CAC), J. teknologi (Sciences \& Engineering), 60, 15-19, (2013)

[5] M.C. Ribas, M.A. Adebayo, L.D.T. Prola, E.C. Lima, R. Cataluna, L.A. Feris, M.J. Puchana-Rosero, F.M. Machado, F.A. Pavan and T. Calvete, Comparison of a homemade cocoa shell activated carbon with commercial activated carbon for the removal of reactive violet 5 dye from aqueous solutions, Chemical Engineering J., 248, 315-326, (2014)

[6] K.N. Aboua, Y.A. Yobouet, K.B. Yao, D.L. Gone and A. Trokourey, Investigation of dye adsorption onto activated carbon from the shells of Macore fruit, J. of Environmental Management, 156, 10-14, (2015) 
[7] S. Ragupathy, K. Raghu and P. Prabu, Synthesis and characterization of $\mathrm{TiO}_{2}$ loaded cashew nut shell activated carbon and photo catalytic activity on BG and MB dyes under sunlight radiation, Spectrochimica Acta Part A: Molecular and Biomolecular Spectroscopy, 138, 314-320, (2015)

[8] B. Heibati, S.R. Couto, M.A. Al-Ghouti, M. Asif, I. Tyagi, S. Agarwal and V.K. Gupta, Kinetics and thermodynamics of enhanced adsorption of the dye AR 18 using activated carbons prepared from walnut and poplar woods, J. of Molecular Liquids, 208, 99-105, (2015)

[9] I.A. Umar, G. Abdulraheem, S. Bala, S. Muhammad and M. Abdullahi, Kinetics, equilibrium and thermodynamics studies of C. I. reactive blue 19 dye adsorption on coconut shell based activated carbon, International Biodeterioration and Biodegradation, 102, 265-273, (2015)

[10]U.T. Un, F. Ates, N. Erginel, O. Ozcan and E. Oduncu, Adsorption of disperse orange 30 dye onto activated carbon derived from holm oak (Quercus Ilex) acorns: A $3^{\mathrm{k}}$ factorial design and analysis, Journal of Environmental Management, 155, 89-96 (2015)

[11]C. Djilani, R. Zaghdoudi, F. Djazi, B. Bouchekima, A. Lallam, A. Modarressi and M. Rogalski, Adsorption of dyes on activated carbon prepared from apricot stones and commercial activated carbon, J. of the Taiwan Institute of Chemical Engineers, 53, 112-121, (2015)

[12]K. Santhy and P. Selvapathy, Removal of reactive dyes from wastewater by adsorption on coir pith activated carbon, Bioresource Technology, 97, 1329-1336, (2006)

[13]V.K. Verma and A.K. Mishra, Kinetic and isotherm modeling of adsorption of dyes onto rice husk carbon, Global NEST J., 12(2), 190-196, (2010)

[14] S. Saeed, S. Khan, S. Saeed and R. Khan, Removal of dyes from textile waste water using adsorption by activated carbon of rice husk, Int. J. of Innovation and Scientific Research, ISSN 2351-8014 17, 191-196, (2015)

[15]M.B. Fabon, G.J. Legaspi, K. Leyesa and M.C. Macawile, Removal of basic dye in water matrix using activated carbon from sugarcane bagasse, Int. Conf. on Innovations in Engineering and Technology, 198-201, (2013)

[16]H. Demiral, I. Demiral, B. Karabacakoglu and F. Tumsek, Adsorption of textile dye onto activated carbon prepared from industrial waste by $\mathrm{Zncl}_{2}$ activation, J. Int. Environmental Application \& Science, 3(5), 381-389, (2008)

[17] M.N. Mahamad, M.A.A. Zaini and Z.A. Zakaria, Preparation and characterization of activated carbon from pineapple waste biomass for dye removal, Int. Biodeterioration and Biodegradation, 102, 274-280, (2015)

[18]J.R. Baseri, P.N. Palanisamy and P. Sivakumar, Preparation and characterization of activated carbon from Thevetia peruviana for the removal of dyes from textile wastewater, Advances in Applied Science Research, 3(1), 377-383, (2012)

[19]P.K. Malik, Use of activated carbons prepared from sawdust and rice-husk for adsorption of acid dyes: a case study of acid yellow 36, Dyes and Pigments, 56, 239249, (2003)

[20]K. Kadirvelu, M. Kavipriya, C. Karthika, M. Radhika, N. Vennilamani and S. Pattabhi, Utilization of various agricultural wastes for activated carbon preparation and application for the removal of dyes and metal ions from aqueous solutions, Bioresource Technology, 87, 129-132, (2003) 
[21]A. Kumar and H.M. Jena, Removal of methylene blue and phenol onto prepared activated carbon from Fox nutshell by chemical activation in batch and fixed-bed column, J. of Cleaner Production, 137, 1246-1259, (2016)

[22] K.W. Jung, B.H. Choi, M.J. Hwang, T.U. Jeong and K.H. Ahn, Fabrication of granular activated carbons derived from spent coffee grounds by entrapment in calcium alginate beads for adsorption of acid orange 7 and methylene blue, Bioresource Technology, 219, 185-195, (2016)

[23] A.M.M. Vargas, A.L. Cazetta, A.C. Martins, J.C.G. Moraes, E.E. Garcia, G.F. Gauze, W.F. Costa and V.C. Almeida, Kinetic and equilibrium studies: adsorption of food dyes acid yellow 6 , acid yellow 23 and acid red 18 on activated carbon from flamboyant pods, Chemical Engineering J., 181-182, 243-250, (2012)

[24] J.V. Nabais, C. Laginhas, M.M.L.R. Carrott, P.J.M. Carrott, J.E.C. Amoros and A.V.N. Gisbert, Surface and porous characterization of activated carbons made from a novel biomass precursor, the esparto grass, Appl. Surf. Sci, 265, 919-924, (2013)

[25]C. Palma, L. Lioret, A. Puen, M. Tobar and E. Contreras, Production of carbonaceous material from avocado peel for its application as alternative adsorbent for dyes removal, Chinese J. of Chemical Engineering, 24, 521-528, (2016)

[26] M. Ghaedi, A.G. Nasab, S. Khodadoust, M. Rajabi and S. Azizian, Application of activated carbon as adsorbents for efficient removal of methylene blue: kinetics and equilibrium study, J. of Industrial and Engineering Chemistry, 20, 2317-2324, (2014)

[27]N.K. Amin, Removal of reactive dye from aqueous solutions by adsorption onto activated carbons prepared from sugarcane bagasse pith, Desalination, 223, 152-161, (2008)

[28]H. Saygili, F. Guzel and Y. Onal, Conversion of grape industrial processing waste to activated carbon sorbent and its performance in cationic and anionic dyes adsorption, $\mathrm{J}$. of Cleaner Production, 93, 84-93, (2015)

[29] R.H. Hesas, A. Arami-niya, W.M.A. Wan Daud and J.N. Sahu, Preparation and characterization of activated carbon from apple waste by microwave-assisted phosphoric acid activation: application in methylene blue adsorption, Bioresources, 8(2), 2950-2966, (2013)

[30]M.E. Fernandez, G.V. Nunell, P.R. Bonelli and A.L. Cukierman, Activated carbon developed from orange peels: batch and dynamic competitive adsorption of basic dyes, Industrial Crops and Products, 62, 437-445, (2014)

[31] A.A.P. Cid, A.M.H. Gonzalez, M.S. Villanueva and A.B. Hernandez, Elimination of textile dyes using activated carbons prepared from vegetable residues and their characterization, J. of Environmental Management, 181, 269-278, (2016)

[32]C. Namasivayam and D. Sangeetha, Recycling of agricultural solid waste, coir pith: removal of anions, heavy metals, organics and dyes from water by adsorption onto $\mathrm{ZnCl}_{2}$ activated coir pith carbon, J. of Hazardous Materials, B135, 449-452, (2006)

[33]L. Yu and Y.M. Luo, The adsorption mechanism of anionic and cationic dyes by Jerusalem artichoke stalk-based mesoporous activated carbon, J. of Environmental Chemical Engineering, 2, 220-229, (2014)

[34] K.Y. Foo and B.H. Hameed, Microwave assisted preparation of activated carbon from pomelo skin for the removal of anionic and cationic dyes, Chemical Engineering J., 173, 385-390, (2011)

[35] V.O. Njoku, K.Y. Foo, M. Asif and B.H. Hameed, Preparation of activated carbons from rambutan (Nephelium lappaceum) peel by microwave-induced $\mathrm{KOH}$ activation for acid yellow 17 dye adsorption, Chemical Engineering J., 250, 198-204, 2014) 
[36] R. Hazzaa and M. Hussein, Adsorption of cationic dye from aqueous solution onto activated carbon prepared from olive stones, Environment Technology \& Innovation, 4, 36-51, (2015)

[37]K.T. Wong, N.C. Eu, S. Ibrahim, H. Kim, Y. Yoon and M. Jang, Recyclable magneticloaded palm shell-waste based activated carbon for the effective removal of methylene blue from aqueous solution, J. of Cleaner Production, 115, 337-342, (2016)

[38] T. Teka and S. Enyew, Study on effect of different parameters on adsorption efficiency of low cost activated orange peels for the removal of methylene blue dye, International J. of Innovation and Scientific Research, ISSN 2351-8014, 8, 106-111, (2014)

[39] B. Ratna and B.S. Padhi, Pollution due to synthetic dyes toxicity and carcinogenicity studies and remediation, Int. J. Environ. Sci, 3, (2012)

[40] J. Georgin, G.L. Dotto, M.A. Mazutti and E.L. Foletto, Preparation of activated carbon from peanut shell by conventional pyrolysis and microwave irradiation-pyrolysis to remove organic dyes from aqueous solutions, J. of Environmental Chemical Engineering, 4, 266-275, (2016)

[41]H. Saygili and F. Guzel, High surface area mesoporous activated carbon from tomato processing solid waste by zinc chloride activation: process optimization, characterization and dyes adsorption, J. of Cleaner Production, 113, 995-1004, (2016)

[42]E.I. El-Shafey, S.N.F. Ali, S. Al-Busafi and H.A.J. Al-Lawati, Preparation and characterization of surface functionalized activated carbons from date palm leaflets and application for methylene blue removal, J. of Environmental Chemical Engineering, 4, 2713-2724, (2016)

[43]P. Sugumaran, V.P. Susan, P. Ravichandran and S. Seshadri, Production and characterization of activated carbon from banana empty fruit bunch and deloxic regia fruit pod, J. of Sustainable Energy and Environment, 3, 125-132, (2012)

[44] M.Z. Alam, E.S. Ameem, S.A. Muyibi and N.A. Kabbashi, The factors affecting the performance of activated carbon prepared from oil palm empty fruit bunches for adsorption of phenol, Chem. Eng. J, 155, 191-198, (2009)

[45]M.J. Ahmed and S.K. Dhedan, Equilibrium isotherms and kinetics modeling of methylene blue adsorption on agricultural wastes-based activated carbons, Fluid Phase Equilib, 317, 9-14, (2012)

[46] Q. Shi, J. Zhang, C. Zhang, C. Li, B. Zhang, W. Hu, J. Xu and R. Zhao, Preparation of activated carbon from cattail and its application for dyes removal, J. of Environmental Sciences, 22(1), 91-97, (2010)

[47] G.Z. Zhu, X.L. Deng, M. Hou, K. Sun, Y.P. Zhang, P. Li and F.M. Liang, Comparative study on characterization and adsorption properties of activated carbons by phosphoric acid activation from corncob and its acid and alkaline hydrolysis residues, Fuel Processing Technology, 144, 255-261, (2016)

[48] J. Hayashi, A. Kazehaya, K. Muroyama and A.P. Watkinson, Preparation of activated carbon from lignin by chemical activation, Carbon, 38, 1873-1878, (2008)

[49]C.L. Williams, T.L. Westover, R.M. Emerson, J.S. Tumuluru and C. Li, Sources of biomass feedstock variability and the potential impact on biofuels production, Bioenergy Research, 9(1), 1-14, (2016)

[50]J. Song, L. Wang and G. Song, Research on influence factors on determination of specific surface area of carbon material by $\mathrm{N}_{2}$ adsorption method, J. of Applied Science and Engineering Innovation, 1(1), 77-82, (2014) 
[51]I. Ozdemir, M. Sahin, R. Orhan and M. Erdem, Preparation and characterization of activated carbon from grape stalk by zinc chloride activation, Fuel Process. Technol,125, 200-206, (2014)

[52] Y. Bulut and H. Aydin, A kinetics and thermodynamics study of methylene blue adsorption on wheat shells, Desalination, 194, 259-267, (2006)

[53] S. Senthilkumaar, P. Varadarajan, K. Porkodi and C. Subbhuraam, Adsorption of methylene blue onto jute fiber carbon: kinetics and equilibrium studies, J. Colloid Interface Sci, 284, 78-82, (2005)

[54]T. Boualem, A. Debab, A. Martinez de Yuso and M.T. Izquierdo, Activated carbons obtained from sewage sludge by chemical activation: gas-phase environmental applications, J. Environ. Manage, 140, 145-215, (2014)

[55]J. Yang and K. Qiu, Development of high surface area mesoporous activated carbons from herb residues, Chem. Eng. J, 167(1), 148-154, (2011). 